B.O. Дьяков, канд. техн. наук, доц. ORCID 0000-0002-6141-8393

A.B. Антонов, канд. техн. наук, ORCID 0000-0001-5701-6087

K.P. Єфремова, магістр ORCID 0000-0001-8131-9061

Дніпропетровський національний університет залізничного транспорту імені академіка В. Лазаряна

\title{
ПРОТИКОРОЗІЙНИЙ ЗАХИСТ ПРИСТРОЇВ КОНТАКТНОЇ МЕРЕЖІ В ЗОНІ СТИКУВАННЯ ЕЛЕКТРИФІКОВАНИХ ДІЛЯНОК ЗАЛІЗНИЦЬ ПОСТІЙНОГО ТА ЗМІННОГО СТРУМУ
}

\begin{abstract}
Метою дослідження є встановлення загрози електрохімічної корозії арматури контактної мережі шляхом визначення потенціалу рейок при зміні координати розташування електрорухомого складу в межах станцій стикування та визначення заходів мінімізації ії впливу.

Для оцінки небезпеки електрокорозії на ділянках тягової мережі змінного струму, які прилягають до станцій стикування, проведені дослідження з визначення величини потенціалів рейок, викликаних протіканням постійного струму.

Встановлено, щуо постійний тяговий струм затікає на ділянки електрифікованих залізниць змінного струму, які розміщені біля станцій стикування, викликаючи можливість електрокорозії залізобетонних опор та фундаментів. При и̧ьому небезпечні потенціали спостерігаються на відстані більше 20 кілометрів від станиії стикування.

На основі отриманих в роботі результатів, запропоновано застосування на ділянках залізниць електрифікованих на змінному струмі, які прилягають до станиій стикування, захист від електрокорозії залізобетонних опор та фундаментів контактної мережі аналогічний захисту на постійному струмі, а саме - розземлення опор.
\end{abstract}

Ключові слова: електрифікований транспорт; контактна мережа; станція стикування; змінний струм; постійний струм; опора; корозія.

Вступ.

Контактна мережа є складним пристроєм в системі тягового електропостачання, який повинен забезпечувати безперебійне живлення електрорухомого складу (ЕРС). Вона не має резерву і тому до іiі елементів висуваються жорсткі вимоги із забезпечення надійності роботи [1].

В умовах експлуатації, опори контактної мережі піддаються механічним навантаженням, які викликані вагою підтримуючих конструкцій, проводів та арматури, а також натягом проводів контактної підвіски. Оскільки на елементи контактної мережі діє навколишнє середовища, відбувається їх атмосферна корозія, яка пришвидшується під дією струмів витоку через металеві деталі контактної мережі [2 - 4].

Протікання електрохімічної корозії арматури контактної мережі та опор призводить до зменшення їх несучої здатності, що разом з дією зовнішнього механічного навантаження, може призвести до руйнування контактної мережі, зупиненню руху потягів і, відповідно, значних економічних збитків.

Процес електрохімічної корозії має місце не лише на ділянках залізниць електрифікованих постійним струмом, а й в місцях стикування електрифікованих ділянок залізниць постійного та змінного струму.

В останньому випадку приділяється занадто мало уваги захисту елементів контактної мережі від електрохімічної корозії, викликаної затіканням постійного тягового струму через рейки на ділянки залізниць електрифікованих змінним струмом, безпосередньо розміщених біля станцій стикування [5 - 7].

Основним критерієм оцінки загрози електрохімічної корозії елементів контактної мережі $\epsilon$ величина потенціалу рейок відносно землі. Тому для оцінки небезпеки електрохімічної корозії на ділянках залізниць електрифікованих змінним струмом, які прилягають до станцій стикування, необхідно проводити поглиблені дослідження.

Мета та завдання. Метою дослідження є встановлення загрози електрохімічної корозії елементів контактної мережі шляхом визначення потенціалу рейок при зміні координати розташування ЕРС в межах станцій стикування та визначення заходів мінімізації їі впливу.

Для досягнення поставленої мети необхідно вирішити ряд завдань:

- визначити характер та об'єкти, на які чинять негативний вплив потенціали рейок;

- визначити заходи, які дозволяють мінімізувати негативний вплив потенціалів рейок на ділянках змінного струму, розташованих поблизу станцій стикування.

$\overline{\text { В.О. Дьяков, А.В. Антонов, К.Р. Сфремова, } 2019}$ 
Матеріал і результати досліджень. На електрифікованих залізницях зустрічаються три види корозійного руйнування: атмосферна корозія - руйнує надземні металеві конструкції контактної мережі та верхню частину опори; грунтова корозія - діє на підземну частину опор та фундаментів; електрохімічна корозія - руйнує ізолятори, залізобетонні опори та фундаменти контактної мережі.

Механізм протікання корозії металу під дією агресивного середовища та електрохімічної корозії носить однаковий характер. Неодмінною умовою протікання процесу корозії є контакт металу 3 електролітом, тобто з вологою (грунтовою, атмосферною) і розчиненими в ній різними хімічними елементами (солями, кислотами, лугами).

В силу неоднорідності структури і складу металу, а також неоднорідності електроліту, різні ділянки поверхні металу, що знаходяться в контакті 3 електролітом, навіть при відсутності зовнішнього електричного поля отримують різні за величиною електрохімічні потенціали, наслідком чого $є$ протікання струму по замкнутому ланцюгу гальвано-корозійної пари, при цьому на поверхні металу завжди будуть ділянки, з яких корозійний струм стікає в електроліт (анод) і ділянки, в які струм повертається назад 3 електроліту в метал (катод). В анодній ділянці відбувається розчинення металу, тобто поступове корозійне руйнування, в катодній - метал зберігається повністю.

Найнебезпечнішою є електрохімічна корозія, оскільки має високу інтенсивність та діє на арматуру опор і фундаментів контактної мережі, яка знаходиться під бетоном.

В місцях стикування електрифікованих залізниць постійного та змінного струму передбачається улаштування захисту всіх опор контактної мережі від електрокорозії $[5,6,8]$.

На сьогодні, стикування електрифікованих ділянок постійного та змінного струму здійснюють за допомогою станцій стикування та нейтральних вставок [8].

Але беручи до уваги те, що рейкова мережа станцій стикування має електричний зв'язок з рейками прилеглих перегонів з'являється небезпека затікання постійного тягового струму на ділянки електрифіковані зміним струмом, що викликає електрокорозійне руйнування залізобетонних опор та фундаментів контактної мережі, рейкових скріплень та інше [9 - 11].

Для оцінки небезпеки електрокорозії на ділянках тягової мережі змінного струму, які прилягають до станцій стикування, необхідно знати величину потенціалів рейок, викликаних протіканням постійного струму.

Зіставимо розрахункові схеми та проведемо визначення величини потенціалів рейок для трьох найбільш частих випадків: при розташуванні ЕРС в горловині станції (рис. 1); при розташуванні ЕРС на міжпідстанційній зоні (МП3) (рис. 3); при відключенні суміжної тягової підстанції (рис. 5). Споживаний струм ЕРС в трьох випадках умовно прийнятий і рівний $I=1000$ А .

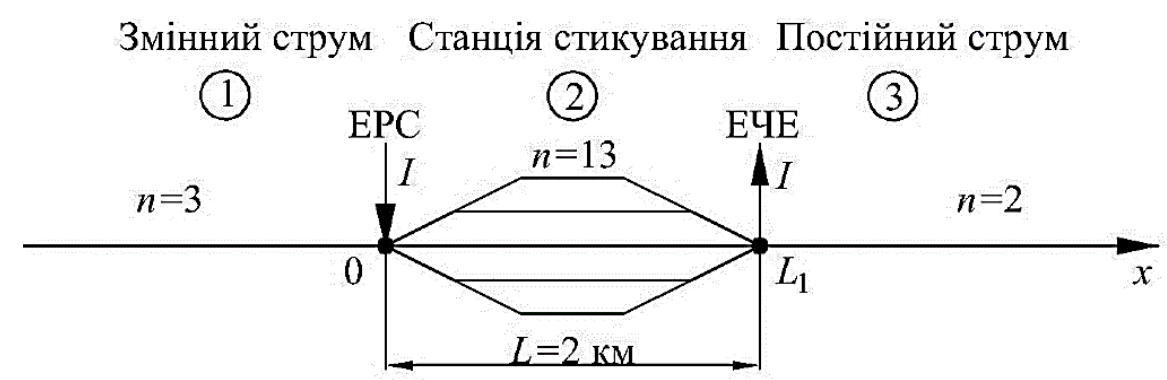

Рисунок 1 - Розрахункова схема при розташуванні ЕРС в горловині станції

Зіставимо систему рівнянь для визначення потенціалів на розрахункових ділянках 1,2 та 3 :

$$
\begin{gathered}
U_{1 \mathrm{PX}}=A_{1} e^{k x}+B_{1} e^{-k x} \\
U_{2 \mathrm{PX}}=A_{2} e^{k x}+B_{2} e^{-k x} \\
U_{3 \mathrm{PX}}=A_{3} e^{k x}+B_{3} e^{-k x}, \\
U_{\mathrm{PX} i}=A_{i} e^{k x}+B_{i} e^{-k x}, \\
I_{\mathrm{PX} i}=-\frac{1}{R_{\mathrm{PB} i}}\left(A_{i} e^{k x}+B_{i} e^{-k x}\right),
\end{gathered}
$$

де $U_{1 \mathrm{PX}}, U_{2 \mathrm{PX}}, U_{3 \mathrm{PX}}$ - потенціали неоднорідної рейкової мережі відповідно на 1,2 та 3 розрахункових зонах, В;

$i$ - номер ділянки;

$k$ - коефіцієнт поширення рейкової мережі, 1/км;

$A_{1}, B_{1}, A_{2}, B_{2}, A_{3}, B_{3}, A_{i}, B_{i}$ - постійні коефіцієнти; 
$R_{\mathrm{PB}}-$ хвильовий опір однорідної рейкової мережі, Ом;

$I_{\mathrm{PX} i}-$ струм неоднорідної рейкової мережі на $i$-ій ділянці, А;

$x$ - поточна координата, км.

Для визначення постійних $A_{i}, B_{i}$ використовуються наступні граничні умови:

$$
\begin{aligned}
& \text { Г.1: } U_{\mathrm{PX}}=0, \text { при } x=-\infty ; \\
& \text { Г.2: } U_{\mathrm{PX}}=0, \text { при } x=\infty ; \\
& \text { Г.3: } U_{\mathrm{PX} 1}=U_{\mathrm{PX} 2}, \text { при } x=0 ; \\
& \text { Г.4: } U_{\mathrm{PX} 2}=U_{\mathrm{PX} 3}, \text { при } x=L_{1} ; \\
& \text { Г.5: } I_{\mathrm{PX} 2}-I_{\mathrm{PX} 1}=I, \text { при } x=0 ; \\
& \text { Г.6: } I_{\mathrm{PX} 2}-I_{\mathrm{PX} 3}=I, \text { при } x=L_{1} .
\end{aligned}
$$

Підставивши граничні умови у рівняння (1) - (5) і розв'язавши систему рівнянь матричним методом, знаходимо значення постійних коефіцієнтів:

$$
\left(\begin{array}{l}
A_{1} \\
B_{1} \\
A_{2} \\
B_{2} \\
A_{3} \\
B_{3}
\end{array}\right)=M^{-1} \cdot C ; \quad\left(\begin{array}{l}
A_{1} \\
B_{1} \\
A_{2} \\
B_{2} \\
A_{3} \\
B_{3}
\end{array}\right)=\left(\begin{array}{c}
1,115 \\
0 \\
-1,821 \\
-2,936 \\
0 \\
-2,232
\end{array}\right)
$$

3 інтервалом у 1 км знаходимо потенціали рейкової мережі шляхом підстановки постійних коефіцієнтів у рівняння (1) - (5). Результати розрахунків приведені у графічному вигляді в залежності від значення перехідного опору на рис. 2.

Значення потенціалів рейкової мережі визначались для значень перехідного опору $r_{\mathrm{n}}=0,25$ Ом·км, $r_{\mathrm{n}}=2,5$ Ом $\cdot$ км, $r_{\mathrm{n}}=5$ Ом км.

a)

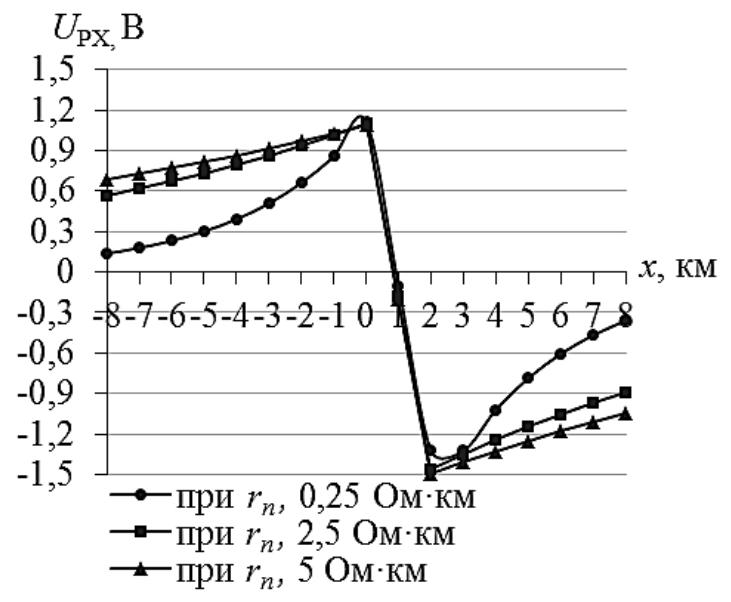

б)

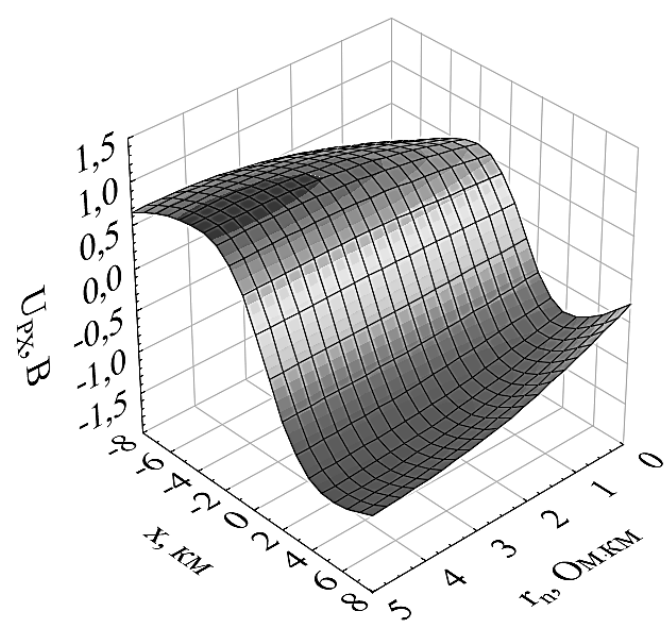

Рисунок 2 - Розподіл потенціалу рейкової мережі при розташуванні ЕРС в горловині станції: а) для трьох контрольних значень $r_{\mathrm{n}}$; б) при інтерполяції - для проміжних значень

Змінний струм Станція стикування Постійний струм

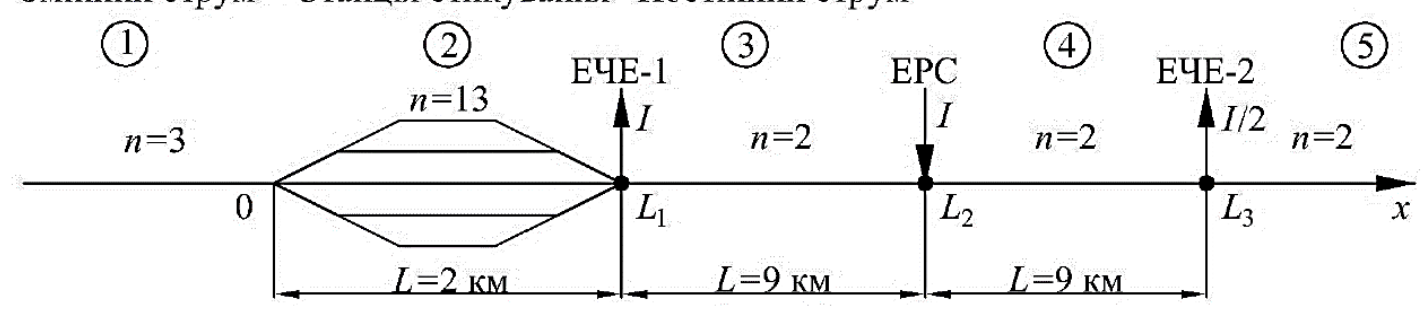

Рисунок 3 - Розрахункова схема при розташуванні ЕРС на МПЗ 
Система рівнянь для визначення струмів та потенціалів на розрахункових ділянках:

$$
\begin{aligned}
& U_{1 \mathrm{PX}}=A_{1} e^{k x}+B_{1} e^{-k x} ; \\
& U_{2 \mathrm{PX}}=A_{2} e^{k x}+B_{2} e^{-k x} ; \\
& U_{3 \mathrm{PX}}=A_{3} e^{k x}+B_{3} e^{-k x} ; \\
& U_{4 \mathrm{PX}}=A_{4} e^{k x}+B_{4} e^{-k x} ; \\
& U_{5 \mathrm{PX}}=A_{5} e^{k x}+B_{5} e^{-k x} .
\end{aligned}
$$

Для визначення постійних $A_{i}, B_{i}$ використовуються наступні граничні умови:

Г.1: $U_{\mathrm{PX}}=0$, при $x=-\infty$;

Г.2: $U_{\mathrm{PX}}=0$, при $x=\infty$;

Г.3: $U_{\mathrm{PX} 1}=U_{\mathrm{PX} 2}$, при $x=0$;

Г.4: $U_{\mathrm{PX} 2}=U_{\mathrm{PX} 3}$, при $x=L_{1}$;

Г.5: $U_{\mathrm{PX} 3}=U_{\mathrm{PX} 4}$, при $x=L_{2}$;

Г.6: $U_{\mathrm{PX} 4}=U_{\mathrm{PX} 5}$, при $x=L_{3}$;

Г.7: $U_{\mathrm{PX} 1}=U_{\mathrm{PX} 2}$, при $x=0$;

Г.8: $I_{\mathrm{PX} 4}-I_{\mathrm{PX} 5}=\frac{I}{2}$, при $x=L_{3}$;

Г.9: $I_{\mathrm{PX} 4}-I_{\mathrm{PX} 3}=I$, при $X=L_{2}$;

Г.10: $I_{\mathrm{PX} 2}-I_{\mathrm{PX} 3}=\frac{I}{2}$, при $x=L_{1}$.

Провівши операції з підстановки та розв'язання отриманих рівнянь по аналогії як для розрахункової схеми (рис. 1) з інтервалом у 1 км маємо потенціали рейкової мережі в залежності від значення перехідного опору в графічному вигляді на рис. 4.

a)

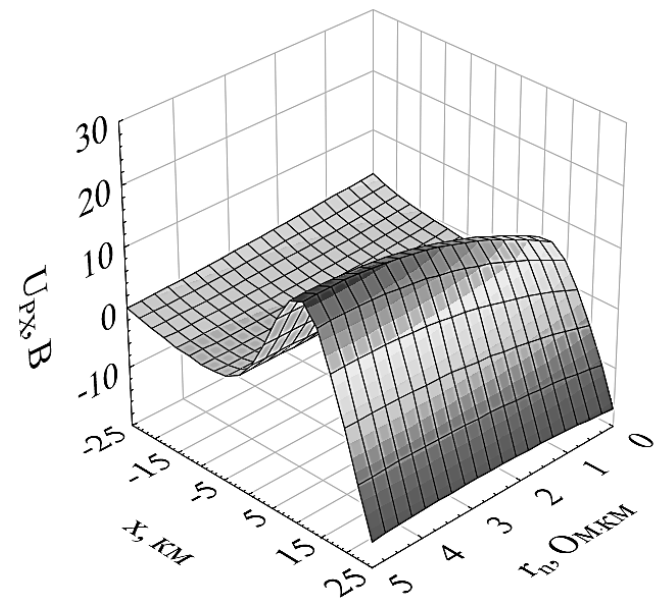

б)

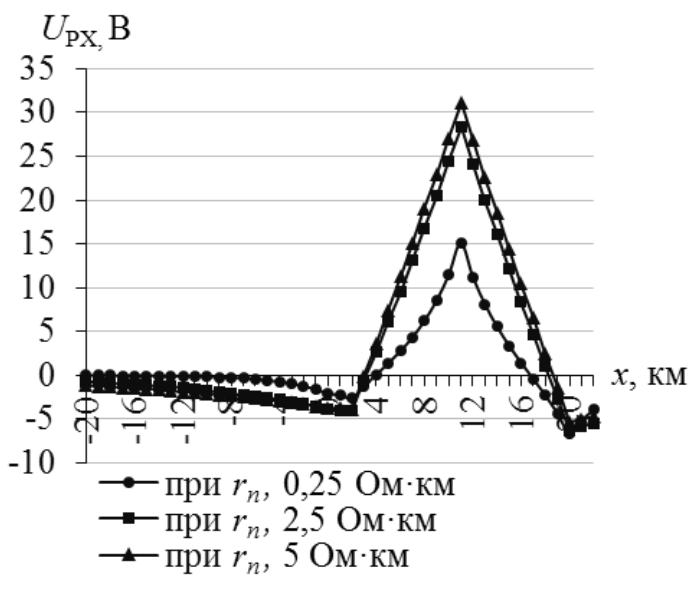

Рисунок 4 - Розподіл потенціалу рейкової мережі при розташуванні ЕРС на МПЗ:

а) для трьох контрольних значень $r_{\mathrm{n}}$; б) при інтерполяції - для проміжних значень

Змінний струм Станція стикування Постійний струм

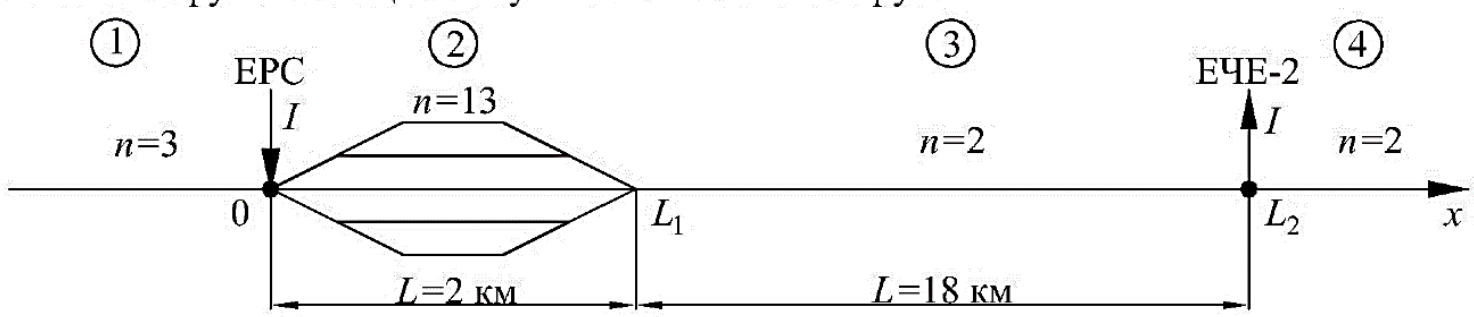

Рисунок 5 - Розрахункова схема при розташуванні ЕРС на МПС при відключенні тягової підстанції ЕЧЕ-1 
Система рівнянь для визначення струмів та потенціалів на розрахункових ділянках:

$$
\begin{aligned}
& U_{1 \mathrm{PX}}=A_{1} e^{k x}+B_{1} e^{-k x} ; \\
& U_{2 \mathrm{PX}}=A_{2} e^{k x}+B_{2} e^{-k x} ; \\
& U_{3 \mathrm{PX}}=A_{3} e^{k x}+B_{3} e^{-k x} ; \\
& U_{4 \mathrm{PX}}=A_{4} e^{k x}+B_{4} e^{-k x},
\end{aligned}
$$

Для визначення постійних $A_{i}, B_{i}$ використовуються наступні граничні умови:

$$
\begin{aligned}
& \text { Г.1: } U_{\mathrm{PX}}=0 \text {, при } x=-\infty ; \\
& \text { Г.2: } U_{\mathrm{PX}}=0 \text {, при } x=\infty ; \\
& \text { Г.3: } U_{\mathrm{PX} 1}=U_{\mathrm{PX} 2}, \text { при } x=0 ; \\
& \text { Г.4: } U_{\mathrm{PX} 2}=U_{\mathrm{PX} 3}, \text { при } x=L_{1} ; \\
& \text { Г.5: } U_{\mathrm{PX} 3}=U_{\mathrm{PX} 4}, \text { при } x=L_{2} ; \\
& \text { Г.6: } I_{\mathrm{PX} 2}-I_{\mathrm{PX} 1}=I, \text { при } x=0 ; \\
& \text { Г.7: } I_{\mathrm{PX} 2}=I_{\mathrm{PX} 3}, \text { при } x=L_{1} ; \\
& \text { Г.8: } I_{\mathrm{PX} 3}-I_{\mathrm{PX} 4}=I, \text { при } x=L_{2} .
\end{aligned}
$$

Провівши операції з підстановки та розв'язання отриманих рівнянь 3 інтервалом у 1 км маємо потенціали рейкової мережі в залежності від значення перехідного опору в графічному вигляді на рис. 6 .

a)

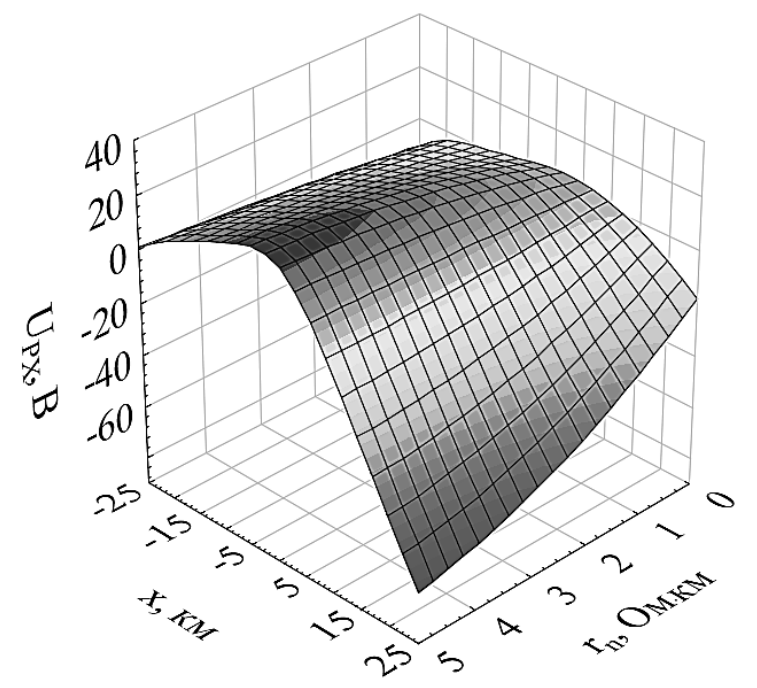

б)

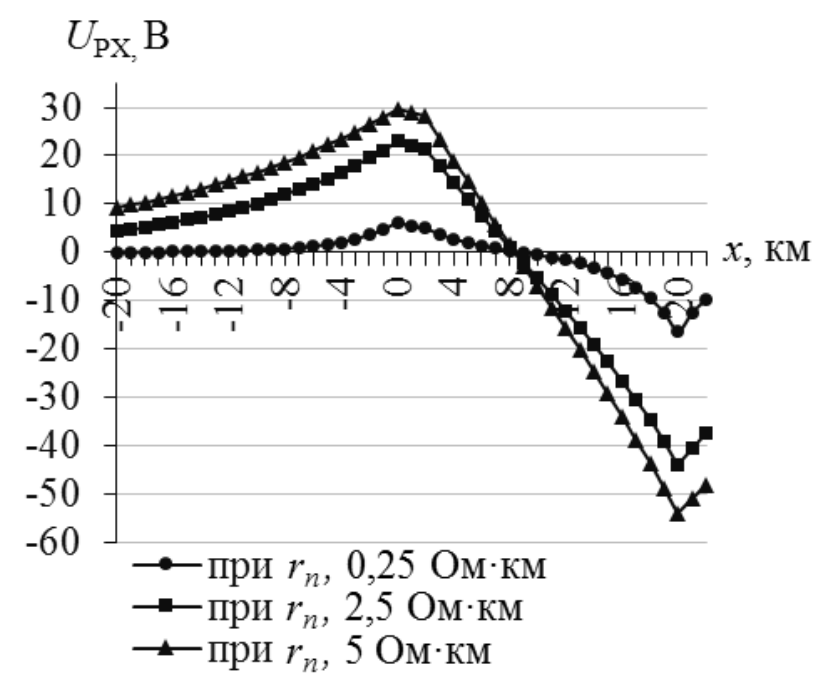

Рисунок 6 - Розподіл потенціалу рейкової мережі при розташуванні ЕРС при відключенні тягової підстанції ЕЧЕ-1:

а) для трьох контрольних значень $r_{\mathrm{n}}$; б) при інтерполяції - для проміжних значень

Проведені дослідження свідчать, що постійний струм затікає на ділянки прилеглих до станцій стикування колій електрифікованих залізниць змінного струму і його величина залежить від розташування електровозу постійного струму поблизу станції стикування та режиму роботи тягової підстанції.

Відомо, що на електрифікованих залізницях змінного струму на залізобетонних опорах з опором понад 100 Ом в заземлюючі спуски встановлюють спеціальні захисні пристрої, які перешкоджають витоку сигнального та тягового струму з рейок в грунт. В той же час, величина допустимого витоку тягового постійного струму з залізобетонної опори в грунт в залежності від нормативно-допустимого моменту опори коливається від 20 до 40 мА, що при опорі опори 100 Ом відповідає потенціалу «рейка - земля» $2 \ldots 4$ В. Перевищення цих значень потенціалів можна вважати небезпечним для корозійного стану залізобетонних опор контактної мережі, які наглухо заземлені на рейки.

Отримані результати, при розрахунковій схемі (рис. 1) показують, що потенціали рейок лежать в дозволених межах. Крім того при збільшені перехідного опору, загроза електрокорозії не з'являється через близьке розташуванням відсмоктуючого фідеру тягової підстанції до ЕРС, що робить неможливим затікання великих постійних струмів у бік перегону змінного струму. Але при збільшенні навантаження, 
наприклад у два рази, відповідно збільшиться величина потенціалу в рейковій мережі в два рази, що різко підвищить небезпеку корозійного руйнування опор контактної мережі.

При умові розташування електровоза в межах МПЗ між підстанціями ЕЧЕ-1 та ЕЧЕ-2 (рис. 3) тяговий струм затікає на прилеглі ділянки змінного струму, викликаючи появу в рейках від'ємного потенціалу (рис. 4), який значно зростає при збільшенні перехідного опору рейка - земля. При таких умовах виникає загроза електрокорозії верхнього поясу опор.

При відключенням підстанції ЕЧЕ-1 (рис. 5) виникає загроза корозійного руйнування фундаментної частини опор контактної мережі на ділянці змінного струму. Навіть на відстані 20 км від станції стикування потенціали рейок значно перевищують допущені значення (рис. 6).

Вказане вище свідчить про те, що на ділянках залізниць електрифікованих змінним струмом, які прилягають до станцій стикування, необхідно застосовувати засоби захисту від електрокорозії опор контактної мережі аналогічні до засобів захисту на електрифікованих ділянках постійного струму на відстані до 20 км і більше, від станції стикування.

Мінімізувати негативний вплив тягових постійних струмів на опори електрифікованих залізниць змінного струму, розташованих поблизу зони стикування систем електротяги постійного та змінного струму, можливо за рахунок розземлення опор. Але в цьому випадку захист контактної мережі від струмів короткого замикання буде мати свої особливості.

\section{Висновки:}

1. В роботі враховані особливості експлуатації контактної мережі в зоні станцій стикування. А саме, що колії електрифікованої ділянки змінного струму мають електричний контакт 3 коліями електрифікованими постійним струмом. Що робить можливим затікання постійного тягового струму на ділянки електрифікованої залізниці змінного струму, викликаючи процес електрокорозії залізобетонних опор та фундаментів контактної мережі.

2. Для оцінки можливості електрокорозії залізобетонних опор та фундаментів контактної мережі, на прилеглих до станцій стикування ділянках залізниць електрифікованих змінним струмом були проведенні дослідження для визначення потенціалів рейкової мережі. За результатами яких можна стверджувати, що постійний тяговий струм затікає на ділянки електрифікованих залізниць змінного струму, які розміщені біля станцій стикування, викликаючи можливість електрокорозії залізобетонних опор та фундаментів. При цьому небезпечні потенціали спостерігаються на відстані 20 кілометрів від станції стикування.

3. На основі отриманих результатів, запропоновано застосування на ділянках залізниць електрифікованих на змінному струмі та що прилягають до станцій стикування, захист від електрокорозії залізобетонних опор та фундаментів контактної мережі аналогічний захисту на постійному струмі заземлення опор контактної мережі на рейки здійснюється через захисні пристрої - іскрові проміжки, діодні заземлювачі з послідовно включеними іскровими проміжками.

4. Найбільш ефективним способом запобігання корозійного руйнування залізобетонних опор та фундаментів контактної мережі $є$ їх розземлення.

\section{Список використаної літератури:}

1. Михеев В.П. Контактные сети и линии электропередачи: Учебник для вузов ж. -д. транспорта. М.: Маршрут, 2003. -416 c.

2. Hans Böhni Corrosion in Reinforced Concrete Structures. - Woodhead Publishing Limited, 2005. - 264

p.

3. Tuutti Kyösti Corrosion of steel in concrete Stockholm. - Swedish Cement and Concrete Research Institute, 1982. $-469 \mathrm{p}$.

4. Kiessling F., Puschmann R., Schmieder A., Schneider E. Contact Lines for Electric Railways: Planning, Design, Implementation, Maintenance. Second Edition. - Wiley, John \& Sons, 2009. - 994 p.

5. Дьяков, В. А. К вопросу о противокоррозионной защите опор контактной сети в зоне станций стыкования / В. А. Дьяков, В. Г. Сыченко, О. И. Гилевич, В. Г. Дзюман, А. В. Дьяков // Залізничний транспорт України. - 2009. - № 5. - с. 26 -27.

6. Дьяков, В. О. Контактна мережа електрифікованих залізниць. Улаштування контактної мережі / В. О. Дьяков, Д. О. Босий, А. В. Антонов - Дніпро: Вид-во ПФ «Стандарт-Сервіс», 2017.

7. Сиченко В.Г., Дьяков В.О., Колесник Д.Р., Полях О.М. Протикорозійний захист суміжних пристроїв у системах тягового електропостачання: Монографія / за загальною редакцією Сиченка В. Г. Дн-ськ: Вид-о ПФ «Стандарт-Сервіс», 2015. - 330 с.

8. Дьяков В. О, Антонов А. В., Малинка С. Ю. Захист нейтральних вставок контактної мережі від перепалів // Електрифікація транспорту. - 2016. - №12. - С. 64 - 70.

9. Дьяков В.О. Противокоррозионная защита смежных сооружений /В.А. Дьяков // Електрифікація транспорту. - 2012. - № 4. - С.30 - 37. 
10. Шевелев Д.А., Дьяков В. О. Дослідження протикорозійного захисту підземних металевих споруд на електролітичній моделі /Д.А.Шевелев, В.О. Дьяков//Електрифікація транспорту.-2011.-№ 1.-с.64-68.

11. Пат. UA 33376, МПК: G01R 31/02. Пристрій захисту рейкових кіл ділянок тяги змінного струму від впливу зворотного постійного тягового струму / Разгонов А. П., Дьяков В. О., Гілевіч О. І., Журавльов А. Ю. - № u200800081 ; заявл. 02.01.2008; опубл. 25.06.2008, Бюл. № 12. - 5 с.

V. Diacov, Cand. Sc. (Eng.), Assoc. Prof. ORCID 0000-0002-6141-8393

A. Antonov, Cand. Sc. (Eng.) ORCID 0000-0001-5701-6087

K. Yefremova, Msc. ORCID 0000-0001-8131-9061

Dnepropetrovsk National University of Railway Transport named after Academician V. Lazaryan

\section{CORROSION PROTECTION OF CONTACT NETWORK ON THE STATION SPLICING ELECTRIFIED RAILWAYS DC AND AC}

The aim of the investigation is to establish the threat contact network electrochemical corrosion of reinforcement by determining the rails potential when electric rolling stock changing the location within the splicing stations and determining measures to minimize its impact.

To assess the danger of electrocorrosion in the sections of the AC traction network, which are adjacent to the splicing stations, investigations were conducted to determine the potential values of the rails caused by the flow of direct current.

It has been established that a direct traction current flows into AC electrified sections of railways, which are located at the splicing stations. That causing the probability of electrocorrosion of reinforced concrete catenary support and foundations. At the same time, hazardous potentials are observed at a distance of more than 20 kilometers from the splicing station.

On the basis of the obtained results, it is proposed to use on the sections of electrified railways and adjacent to splicing stations, the protection against electro-corrosion of reinforced concrete catenary supports and foundations of the contact network is similar to the protection of direct current. The catenary supports grounding on the rails is carried out through protective devices - spark gaps, diode earthing switches with sequentially switched spark gaps.

The most effective way to prevent corrosive destruction of reinforced catenary concrete supports and foundations of the contact network is to earthen them.

Keywords: electrified transport; contact network; splicing station; alternating current; direct current ; catenary support; corrosion.

\section{References:}

1. Miheev V.P. Kontaktnye seti i linii ehlektroperedachi: Uchebnik dlya vuzov zh. -d. transporta. - M.: Marshrut, 2003. - $416 \mathrm{~s}$.

2. Hans Böhni Corrosion in Reinforced Concrete Structures. - Woodhead Publishing Limited, 2005. $264 \mathrm{p}$.

3. Tuutti Kyösti Corrosion of steel in concrete Stockholm. - Swedish Cement and Concrete Research Institute, 1982. $-469 \mathrm{p}$.

4. Kiessling F., Puschmann R., Schmieder A., Schneider E. Contact Lines for Electric Railways: Planning, Design, Implementation, Maintenance. Second Edition. - Wiley, John \& Sons, 2009. - 994 p.

5. D'yakov, V. A. K voprosu o protivokorrozionnoj zashchite opor kontaktnoj seti v zone stancij stykovaniya / V. A. D'yakov, V. G. Sychenko, O. I. Gilevich, V. G. Dzyuman, A. V. D'yakov // Zaliznichnij transport Ukraïni. - 2009. - № 5. - s. $26-27$.

6. Diakov, V. O. Kontaktna merezha elektryfikovanykh zaliznyts. Ulashtuvannia kontaktnoi merezhi / V. O. Diakov, D. O. Bosyi, A. V. Antonov - Dnipro: Vyd-vo PF «Standart-Servis», 2017.

7. Sychenko V.H., Diakov V.O., Kolesnyk D.R., Poliakh O.M. Protykoroziinyi zakhyst sumizhnykh prystroiv u systemakh tiahovoho elektropostachannia: Monohrafiia / za zahalnoiu redaktsiieiu Sychenka V. H. Dn-sk: Vyd-o PF «Standart-Servis», 2015. - 330 s.

8. Diakov V. O, Antonov A. V., Malynka S. Yu. Zakhyst neitralnykh vstavok kontaktnoi merezhi vid perepaliv // Elektryfikatsiia transportu. - 2016. - №12. - S. $64-70$.

9. D'yakov V.O. Protivokorrozionnaya zashchita smezhnyh sooruzhenij /V.A. D'yakov // Elektrifikaciya transportu. - 2012. - № 4. - S.30 - 37 .

10. Shevelev D.A., Diakov V. O. Doslidzhennia protykoroziinoho zakhystu pidzemnykh metale $\neg$ vykh sporud na elektrolitychnii modeli /D.A.Shevelev, V.O. Diakov//Elektryfikatsiia transportu.-2011.-№ 1.-s.64-68. 
11. Pat. UA 33376, MPK: G01R 31/02. Prystrii zakhystu reikovykh kil dilianok tiahy zminnoho strumu vid vplyvu zvorotnoho postiinoho tiahovoho strumu / Razghonov A. P., Diakov V. O., Hilevich O. I., Zhuravlov A. Yu. - № u200800081 ; zaiavl. 02.01.2008; opubl. 25.06.2008, Biul. № 12. - 5 s.

B.O. Дьяков, канд. техн. наук, доц., ORCID 0000-0002-6141-8393

A.B. Антонов, канд. техн. наук, ORCID 0000-0001-5701-6087

E.P. Ефремова, магистр ORCID 0000-0001-8131-9061

Днепропетровский национальный университет железнодорожного транспорта имени академика В. Лазаряна

\title{
ПРОТИВОКОРРОЗИОННАЯ ЗАЩИТА УСТРОЙСТВ КОНТАКТНОЙ СЕТИ В ЗОНЕ СТЫКОВАНИЯ ЭЛЕКТРИФИЦИРОВАННЫХ УЧАСТКОВ ЖЕЛЕЗНЫХ ДОРОГ ПОСТОЯННОГО И ПЕРЕМЕННОГО ТОКА
}

\begin{abstract}
Целью исследования является установление угрозы электрохимической коррозии арматуры контактной сети путем определения потенциала рельсов при изменении координаты расположения электроподвижного состава в пределах станций стыкования и определение мер минимизации ее влияния.

Для оценки опасности электрокоррозии на участках тяговой сети переменного тока, которые прилегают к станциям стыкования, проведены исследования по определению величины потенциалов рельсов, вызванных протеканием постоянного тока.

Установлено, что постоянный тяговый ток затекает на участки электрифицированных железных дорог переменного тока, которые расположены у станиий стыкования, вызывая вероятность электрокоррозии железобетонных опор и фундаментов. При этом опасные потенциалы наблюдаются на расстоянии более 20 километров от станциии стыкования.

На основании полученных в работе результатов, предложено применение на участках железных дорог, электрифицированных на переменном токе, прилегающих к станциям стыкования, защиту от электрокоррозии железобетонных опор и фундаментов контактной сети аналогичную защите на постоянном токе, а именно - разземление опор.
\end{abstract}

Ключевые слова: электрифицированный транспорт; контактная сеть; станция стыкования; переменный ток; постоянный ток; опора; коррозия. 